\title{
Seleksi Produksi Tahap Pertama Klon-Klon Ubijalar Berkadar Gula Tinggi
}

\author{
Preliminary Production Selection of Sweet Potato Clones \\ with High Sugar Contents
}

\author{
Joko Restuono ${ }^{1 *}$, Febria Cahya Indriani1), Wiwit Rahajeng1), Rahmi Yulifianti1) \\ 1) Balai Penelitian Tanaman Aneka Kacang dan Umbi, Jl. Raya Kendalpayak Km 8, Malang \\ ${ }^{*}$ Penulis untuk korespodensi E-mail: jrestu71@gmail.com
}

\begin{abstract}
Sweetpotato has high nutritional and commercial values, such as Cilembu variety which is known as honey sweet potato with high selling price due to its desired sweet taste (high sugar content). The demand for Cilembu has been increasing in Indonesia as well as for export purpose. However, Cilembu is locally adapted in its origin area (Kuningan, West Java) and less adapted in other areas. This limits the development of Cilembu cultivation. Therefore, breeding to create new varieties with similar or higher sugar content, higher productivity and widely adapted areas than Cilembu is essential. This study aimed to evaluate the yield potential and sugar content of selected sweetpotato promising clones. About 40 sweetpotato clones, including Cilembu and Sari as variety checks were grown in Poncokusumo, Malang. The trial used a randomized block design with three replications. The variables observed were yield potential, harvest index, dry matter, moisture and reducing sugar contents. The results showed that 31 clones had higher dry matter contents than those of check varieties. Three clones had high yields: namely MSU 15018-53 (38.23 t/ha), MSU 15008-36 (36.37 t/ha) and MSU 15018-55 (35.20 t/ha). There were five clones (MSU15008-22, MSU 15013-35, MSU 15013-01, MSU 15016-69, and MSU 15007-28), which contained higher reducing sugar compared to Cilembu (13.30 Brix). These clones are promising to be released as new varieties with high sugar contents.
\end{abstract}

Keywords: sweet potato, production, high sugar content, cilembu

\section{INTISARI}

Ubijalar merupakan komoditas yang memiliki nilai gizi dan komersial yang tinggi, contohnya ubi Cilembu yang dikenal juga dengan ubi madu yang harga jualnya tinggi. Ubi ini disukai konsumen karena rasanya yang manis (memiliki kadar gula tinggi). Permintaan ubi Cilembu semakin meningkat, tidak hanya di dalam negeri tetapi juga sudah diekspor ke mancanegara. Daya adaptasi ubi Cilembu yang sempit (umumnya tumbuh baik bila ditanam di daerah Cilembu, Jawa Barat) menjadi kendala dalam pengembangannya. Salah satu upaya yang dilakukan adalah dengan merakit varietas unggul baru yang memiliki produktivitas tinggi, kadar gula tinggi serta mampu beradaptasi luas. Penelitian bertujuan untuk mengevaluasi potensi hasil dan kadar gula klon-klon harapan ubi jalar. Penelitian dilaksanakan di kecamatan Poncokusumo kabupaten Malang. Materi genetik menggunakan 40 klon ubi jalar termasukpembanding Sari dan Cilembu sebagai varietas cek. Rancangan perlakuan menggunakan Rancangan Acak Kelompok (RAK) tiga ulangan. Variabel yang diamati 
: hasil panen, indeks panen, bahan kering umbi, kadar air dan kadar gula reduksi. Hasil pengamatan menunjukkan bahwa 31 klon memiiliki kadar bahankering lebih tinggi dibandingkan dengan kedua varietas cek. Rata-rata produktivitas umbi segar tertinggi dipeoleh pada klon MSU 15018-53 (38,23 t/ha), diikuti MSU 15008-36 (36,37 t/ha) dan MSU 15018-55 (35,20 t/ha). Terdapat lima klon yang memiliki kadar gula reduksi lebih tinggi dari varietas pembanding Cilembu (13,30 Brix), yaitu klon MSU 15008-22, MSU 15013-35, MSU 15013-01, MSU 15016-69, dan MSU 15007-28. Klonklon ini berpeluang untuk dirilis sebagai varietas unggul baru dengan kadar gula tinggi.

Kata Kunci: ubijalar, produksi, kadar gula tinggi, cilembu

\section{PENDAHULUAN}

Ubi jalar saat ini sudah dikenal luas di masyarakat, berbagai produk olahan dari bahan baku ubi jalar juga banyak diminati. Selain sebagai sumber karbohidrat, ubijalar juga kaya vitamin dan mineral serta antioksidan yang baik bagi kesehatan. Kure (2012) menyatakan ubi jalar sebagai pangan masa depan, hal ini karena komoditas ini mempunyai prospek sebagai penganti beras yang merupakan sumber pangan utama di Indonesia. Jusuf et al. (2006) menyampaikan ubijalar potensial digunakan dalam program diversifikasi pangan, selain itu juga merupakan bahan baku pada industri pangan maupun non pangan antara lain: sirup, kosmetika, campuran saus, lem, tepung komposit untuk bahan roti dan aneka kue. Pada umumnya ubi jalar digunakan sebagai bahan baku industri makanan, kebutuhan ubi jalar di dalam negeri dipastikan meningkat sejalan dengan meningkatnya jumlah penduduk dan semakin berkembangnya industri berbahan baku ubi jalar (Saleh et al. 2008).

Minat masyarakat mengkonsumsi ubi jalar semakin tinggi terutama terhadap ubi jalar dengan kadar gula tinggi karena rasanya yang manis, yang popular disebut ubi madu. Ubi jalar manis yang saat ini dikenal masyarakat adalah ubi cilembu. Ubi jalar Cilembu berasal dari Cilembu, kabupaten Sumedang Jawa Barat. Ubi jalar ini terkenal karena bersifat khas, yaitu memiliki rasa manis. Menurut Solohin et al. (2017) keragaman sifat lahan diantara lokasi yang berbeda berperan dalam perbedaan performa pertumbuhan dan produksi tanaman. Terdapat beberapa sifat sifat kimia dan fisik tanah, elevasi serta iklim yang berbeda berpengaruh terhadap kemanisannya. Ubi jalar Cilembu berasal dari Cilembu, kabupaten Sumedang Jawa Barat. Ubi jalar ini terkenal karena bersifat khas, yaitu memiliki rasa manis.

Menurut Fatonah (2012), ubijalar mentah pada umumnya memiliki kadar gula total sebesar 28,38\% (bk), sedangkan ubi Cilembu mentah memiliki kadar gula total sebesar $53,57 \%$ (bk). Ubijalar jenis ini memiliki nilai ekonomis yang tinggi, digemari oleh pelaku 
usaha dan konsumen karena pada saat dibakar dalam oven mengeluarkan cairan manis layaknya madu. Permintaan terhadap ubi terus meningkat namun dihadapkan pada kendala rendahnya produktivitas yaitu 5,7 t/ha dan hanya dipanen sekali dalam setahun karena umurnya dalam, berkisar antara 6-7 bulan (Maulana et al., 2011). Selain itu ubi Cilembu ini memiliki daya adaptasi yang sempit (spesifik lokasi) sehingga menyulitkan untuk dikembangkan ke daerah lain. Seiring meningkatnya permintaan pasar baik di Indonesia maupun di mancanegara, harus diimbangi dengan peningkatan produksi sehingga diperlukan perakitan varietas unggul baru yang memiliki karakter kadar gula tinggi dengan produktivitas tinggi dan memiliki kemampuan adaptasi luas.

\section{BAHAN DAN METODE}

Penelitian dilaksanakan di desa Karangnongko, Kecamatan Poncokusumo, Malang tahun 2017. Rancangan perlakuan menggunakan Rancangan Acak Kelompok (RAK) tiga ulangan, materi genetik 40 klon ubijalar yang terdiri atas 38 klon dengan 2 varietas pembanding (Cilembu dan Sari). Luas plot $2 \times 5 \mathrm{~m}$ dengan jarak tanam $100 \mathrm{~cm} \times 25 \mathrm{~cm}$. Variabel yang diamati : potensi (t/ha), bahan kering umbi (\%), indeks panen (\%), kadar air (\%) dan kadar gula reduksi (brix).

\section{Metode analisis kadar gula}

Analisis kadar bahan kering dengan mengeringkan umbi yang dipotong dadu kecil dalam oven pada suhu $60^{\circ} \mathrm{C}$ selama 24 jam, lalu ditimbang. Bahan kering ini selanjutnya digiling dan digunakan sebagai sampel analisis kimia kadar gula (setiap aksesi diulang dua kali). Kadar gula dianalisis dengan metode Nelson-Somogy (Sudarmadji et al. 1997). Penentuan kadar gula reduksi dilakukan dengan menimbang sampel 100-150 mg (lolos ayak 60 mesh tambahkan $10 \mathrm{ml}$ aquadest shaker selama 1 jam, pindahkan larutan dan encerkan hingga volumenya $100 \mathrm{ml}$. Saring filtrat pada erlemmeyer $250 \mathrm{ml}$. Larutan hasil pengenceran diambil $1 \mathrm{ml}$ kemudian ditambahkan $1 \mathrm{ml}$ Nelson. Panaskan selama 20 menit dan dinginkan, setelah dingin larutan sampel ditambah $1 \mathrm{ml}$ Arsenolmolybdat dan ditambah $7 \mathrm{ml}$ aquades. Kocok dengan vortex lalu ukur absorbansinya pada spektrofotometer dengan panjang gelombang $540 \mathrm{~nm}$. Kemudian bandingkan dengan kurva standar untuk gula reduksi yang telah dibuat sebelumnya. 


\section{HASIL DAN PEMBAHASAN}

Hasil analisis ragam menunjukkan berbeda nyata pada taraf 0,01 antar klon untuk semua karakter (Tabel 1). Hal ini mengindikasikan masing-masing klon menunjukkan sifat genetik yang berbeda untuk semua karakter yang diamati.

Tabel 1. Analisis ragam klon-klon ubi jalar hasil seleksi produksi tahap pertama Klon-klon ubijalar Berkadar gula tinggi, Poncokusumo 2017

\begin{tabular}{|c|c|c|c|c|}
\hline \multirow{2}{*}{ Karakter } & \multicolumn{3}{|c|}{ Kuadrat tengah } & \multirow{2}{*}{ KK (\%) } \\
\hline & Blok & Klon & Galat & \\
\hline Produksi & 12,356 & $78,510^{\star \star}$ & 14,175 & 14,08 \\
\hline Kadar bahan kering umbi & 4,846 & $45,672^{* \star}$ & 3,984 & 6,65 \\
\hline Produksi bahan kering umbi & 0,296 & $9,532^{* *}$ & 1,621 & 15,90 \\
\hline Indekss panen & 17,896 & $126,014^{\star *}$ & 23,081 & 8,46 \\
\hline Kadar air & 0,08 & $43,82^{\star *}$ & 0,10 & 0,44 \\
\hline Kadar gula & 0,03 & $8,37^{\star \star}$ & 0,01 & 0,84 \\
\hline
\end{tabular}

\section{Potensi Hasil}

Potensi hasil umbi pada penelitian ini sangat beragam, berkisar antara 16,63-38,23 tha (Tabel 2). Rata-rata tertinggi potensi hasil adalah klon MSU 15018-53 dan klon MSU 15008-36, masing-masing sebesar 38,23 t/ha dan 36,37 t/ha. Menurut Mekonnen et al. (2015) produksi ubi jalar segar merupakan kriteria seleksi yang merupakan indikator tingkat adaptasi suatu klon terhadap kondisi lingkungan tertentu. Masing-masing klon/varietas akan menunjukkan respon yang berbeda yang terlihat dari pertumbuhan vegetatif dan generatif (Saitama et al. 2017). Karakter-karakter tersebut dapat digunakan sebagai dasar seleksi dalam menentukan klon-klon yang mampu beradaptasi pada kondisi tertentu.

\section{Kadar Bahan Kering, kadar air dan produksi bahan kering}

Kadar bahan kering umbi klon-klon yang dievaluasi rata-rata sebesar 30,47\% dengan kisaran 20,70-37,87\% (Tabel 2). Kadar bahan kering tertinggi berturut-turut klon MSU15008-11 dan klon MSU 15019-48 yang memiliki kadar bahan kering sebesar 37,9\% dan $35,90 \%$. Kadar bahan kering merupakan salah satu kriteria seleksi karena dapat digunakan sebagi indikator kualitas umbi. Kadar bahan kering penting dalam seleksi ubijalar karena menyangkut produksi bahan kering dan rasa enak umbi (Wang 1982). Produksi bahan kering umbi merupakan karakter yang cukup penting untuk diketahui, industri pangan memerlukan kadar bahan kering umbi yang tinggi. Kadar bahan kering umbi yang tinggi dan didukung dengan hasil umbi yang tinggi akan didapatkan produksi bahan kering yang tinggi. Terdapat empat klon ubi jalar yang memiliki produksi bahan kering umbi $>10$ t/ha yaitu MSU 15008-36, MSU 15018-53, MSU 15018-55, dan MSU 15019-49 dengan produksi bahan 
kering umbi masing-masing adalah 12,7; 12,3; 11,5; dan 10,4 t/ha. Sedangkan varietas pembanding Sari dan Cilembu hanya memiliki rata-rata produksi bahan kering umbi masingmasing 5,9 dan 4,4 t/ha.

Kadar air umbi dari 40 klon yang diuji menunjukkan nilai yang cukup bervariasi yaitu berkisar antara $65,23-80,63 \%$ dengan rata-rata $71,22 \%$ (Tabel 2). Kadar air umbi tertinggi ditunjukkan oleh klon MSU 15007-39 diikuti oleh klon MSU 15018-22 masing masing sebesar 80,63\% dan 77,57\%. Menurut Indriani et al. 2016 terdapat Korelasi antara kadar air umbi segar (\%) dengan kadar bahan kering (\%) sebesar $(r=-0,86$, hubungan menunjukkan korelasi negatif, artinya semakin tinggi kadar air maka kadar bahan kering semakin rendah. Hal yang sama dinyatakan oleh Ginting (2012) kadar air umbi berkorelasi negatif dengan bahan kering.

Untuk skala industri, tidak cukup hanya umbi dengan kadar bahan kering tinggi, beberapa karakter yang menunjang antara lain bentuk umbi, tidak rengkah dan laju oksidasi rendah. Hasil identifikasi plasma nutfah menunjukkan pada umumnya klon-klon ubi jalar dengan daging umbi kuning memiliki kadar bahan kering $>30 \%$ dan klon-klon ubi jalar dengan daging umbi orange umumnya memiliki kandungan bahan kering sedang - rendah ( $<30 \%$ ) (Indriani, 2016).

\section{Indeks Panen}

Rata-rata Indeks panen tertinggi dicapai oleh klon MSU 15018-55 diikuti oleh klon MSU 15008-36 masing-masing sebesar $68,6 \%$ dan $65,4 \%$ dan lebih tinggi dari rata-rata Indeks panen total sebesar $56,8 \%$ (Tabel 2). Indeks panen terendah dihasilkan oleh klon MSU 15001-01 sebesar 42,3\%. Indeks panen meskipun bukan merupakan kriteria utama dalam seleksi ubijalar namun dapat untuk menduga kelebatan tajuk yang dihasilkan oleh klon/varietas yang dievaluasi. Hasil umbi berkorelasi positif dengan indeks panen, bobot seluruh tanaman dan jumlah umbi per tanaman. Tingginya nilai indeks panen menunjukkan

distribusi asimilat lebih besar ke umbi sedangkan indeks panen yang rendah mengindikasikan distribusi asimilat lebih besar ke bagian atas tanaman (Jha, 2012). 
Tabel 2. Rata-rata produksi, kadar bahan kering, produksi bahan kering umbi, indeks panen, kadar air dan kadar gula reduksi klon-klon ubijalar, Poncokusumo, 2017.

\begin{tabular}{|c|c|c|c|c|c|c|c|}
\hline No & $\begin{array}{c}\text { Klon/ } \\
\text { Varietas }\end{array}$ & $\begin{array}{l}\text { Produksi } \\
\text { (t/ha) }\end{array}$ & $\begin{array}{c}\text { Kadar bahan } \\
\text { kering umbi } \\
(\%)\end{array}$ & $\begin{array}{c}\text { Produksi bahan } \\
\text { kering umbi } \\
\text { (t/ha) }\end{array}$ & $\begin{array}{l}\text { Indekss } \\
\text { panen } \\
(\%) \\
\end{array}$ & $\begin{array}{c}\text { Kadar air } \\
(\%)\end{array}$ & $\begin{array}{c}\text { Kadar gula } \\
\text { reduksi } \\
\text { (Brix) }\end{array}$ \\
\hline 1 & MSU 15001-01 & $19,8 \mathrm{klm}$ & $28,7^{j-n}$ & $5,6^{\text {no }}$ & $42,3^{m}$ & $71.43^{i}$ & $11.00 \mathrm{gh}$ \\
\hline 2 & MSU 15006-01 & $24,6^{f-k}$ & $32,5^{c-i}$ & $8,1^{e-k}$ & $63,2 \mathrm{abc}$ & $68.87 \mathrm{mn}$ & $10.00 \mathrm{kl}$ \\
\hline 3 & MSU 15007-08 & $32,2^{a-d}$ & $29,3^{i-n}$ & $9,5^{c-f}$ & $58,3^{b-i}$ & $72.87^{h}$ & $9.53^{p}$ \\
\hline 4 & MSU 15007-28 & $24,5 \mathrm{~g}-\mathrm{k}$ & 34,4 b-e & $8,5^{d-j}$ & $48,4 \mathrm{klm}$ & $67.93^{p}$ & $13.37^{e}$ \\
\hline 5 & MSU 15007-39 & $28,4^{d-i}$ & $20,7^{r}$ & 5,9 1-0 & 61,1 a-f & 80.63 a & $10.00 \mathrm{kl}$ \\
\hline 6 & MSU 15007-41 & 25,1 e-k & 28,0 k-o & $7,1^{\text {h-n }}$ & $51,8^{\text {h-l }}$ & $71.07^{i}$ & $10.33^{j}$ \\
\hline 7 & MSU 15008-02 & $28,3 d-i$ & $26,3^{n-q}$ & 7,4 g-n & 59,8 b-g & $75.33 \mathrm{de}$ & $9.83 \mathrm{mn}$ \\
\hline 8 & MSU 15008-07 & $20,6 \mathrm{klm}$ & $32,6^{c-h}$ & $6,8^{i-n}$ & $47,6 \mathrm{klm}$ & $65.23^{t}$ & 13.00 \\
\hline 9 & MSU 15008-11 & $21,5 \mathrm{j}-\mathrm{m}$ & 37,9 a & 8,1 e-k & 54,7 e-k & $65.47^{t}$ & $11.00 \mathrm{gh}$ \\
\hline 10 & MSU 15008-22 & 31,0 b-g & 29,9 h-l & $9,3^{d-g}$ & 61,7 a-e & 69.53 I & $15.33^{a}$ \\
\hline 11 & MSU 15008-36 & $36,4 a b$ & $35,1^{a-d}$ & $12,7^{a}$ & $65,4 a b$ & $77.10^{b}$ & $8.00^{r}$ \\
\hline 12 & MSU 15008-69 & $27,1^{d-j}$ & $32,5^{c-i}$ & $8,8^{d-i}$ & $53,2 \mathrm{~g}-\mathrm{k}$ & 68.10 op & $11.13 \mathrm{~g}$ \\
\hline 13 & MSU 15009-04 & 32,6 a-d & $27,0^{1-q}$ & $8,8^{d-i}$ & 58,0 b-i & $74.40 \mathrm{fg}$ & 8.939 \\
\hline 14 & MSU 15009-12 & $27,0^{d-j}$ & 25,1 opq & $6,8^{i-n}$ & $56,5^{c-j}$ & $75.80 \mathrm{~cd}$ & $11.00 \mathrm{gh}$ \\
\hline 15 & MSU 15009-13 & 30,3 b-g & 32,9 b-h & 10,0 cde & $48,9 \mathrm{j}-\mathrm{m}$ & 66.73 rs & $9.93 \mathrm{Im}$ \\
\hline 16 & MSU 15009-22 & $31,5 \mathrm{bcd}$ & $27,3^{1-q}$ & $8,6^{d-j}$ & $62,8 a b c$ & $69.70 \mathrm{kl}$ & $11.00 \mathrm{gh}$ \\
\hline 17 & MSU 15009-28 & $28,6^{d-i}$ & $24,7 \mathrm{pq}$ & $7,1^{\mathrm{h}-\mathrm{n}}$ & $54,9^{d-k}$ & 75.67 cde & $11.93^{f}$ \\
\hline 18 & MSU 15011-08 & 31,0 b-e & 24,8 opq & $7,7^{\mathrm{f}-\mathrm{n}}$ & $57,4^{c-i}$ & $76.00^{c}$ & $10.30^{j}$ \\
\hline 19 & MSU 15013-01 & $27,7^{d-i}$ & $31,9 \mathrm{~d}-\mathrm{j}$ & $8,8^{d-i}$ & $50,8^{i-1}$ & $69.00 \mathrm{~m}$ & $14.13^{c}$ \\
\hline 20 & MSU 15013-06 & $16,6 \mathrm{~m}$ & $34,1^{b-f}$ & $5,7 \mathrm{mno}$ & $44,1^{I m}$ & $68.10 \mathrm{op}$ & $10.00 \mathrm{kl}$ \\
\hline 21 & MSU 15013-23 & $31,9 \mathrm{bcd}$ & $30,9^{f-k}$ & 9,9 cde & 63,1 abc & $71.03^{i}$ & $10.00 \mathrm{kl}$ \\
\hline 22 & MSU 15013-35 & $17,8 \mathrm{Im}$ & $35,6 a b c$ & $6,3^{\mathrm{k}-\mathrm{o}}$ & $47,2 \mathrm{klm}$ & 67.17 qr & $15.00^{b}$ \\
\hline 23 & MSU 15013-44 & $26,8^{d-j}$ & 29,7 h-m & 7,9 e-I & $63,1 a b c$ & $67.60 \mathrm{pq}$ & 11.33 \\
\hline 24 & MSU 15016-24 & $24,6^{\mathrm{f}-\mathrm{k}}$ & $30,2 \mathrm{~g}-1$ & $7,4^{g-n}$ & $49,0 \mathrm{j}-\mathrm{m}$ & 67.23 qr & 12.80 \\
\hline 25 & MSU 15016-36 & $28,0^{d-i}$ & $26,5 \mathrm{~m}-\mathrm{q}$ & 7,3 g-n & $63,5 a b c$ & $74.50^{f}$ & $10.00 \mathrm{kl}$ \\
\hline 26 & MSU 15016-49 & $27,7^{d-i}$ & $29,3^{i-n}$ & 8,1 e-k & $63,5 a b c$ & $72.90^{h}$ & 9.73 no \\
\hline 27 & MSU 15016-69 & $18,0 \mathrm{~lm}$ & $32,9 d-i$ & 5,9 1-o & 59,0 b-h & 68.47 no & $13.60^{d}$ \\
\hline 28 & MSU 15016-113 & $24,8^{f-k}$ & 34,7 a-e & $8,6^{d-j}$ & $65,3 a b$ & $70.50^{j}$ & $10.80^{i}$ \\
\hline 29 & MSU 15016-126 & $30,7^{b-f}$ & $24,5 \mathrm{q}$ & $7,5^{\mathrm{f}-\mathrm{n}}$ & $57,9 \mathrm{~b}-\mathrm{i}$ & $75.27^{e}$ & 9.87 Imn \\
\hline 30 & MSU 15018-22 & $29,5^{c-h}$ & 25,1 орq & $7,4^{g-n}$ & $62,7^{a-d}$ & $77.57^{b}$ & $9.57^{p}$ \\
\hline 31 & MSU 15018-53 & $38,2^{a}$ & $32,2 \mathrm{~d}-\mathrm{i}$ & $12,3 a b$ & 59,2 b-h & $71.03^{i}$ & $11.13 \mathrm{~g}$ \\
\hline 32 & MSU 15018-55 & $35,2 a b c$ & $32,6^{c-h}$ & $11,5 a b c$ & $68,6^{a}$ & $77.40^{b}$ & $9.00 \mathrm{q}$ \\
\hline 33 & MSU 15019-24 & $25,0^{e-k}$ & 27,8 k-p & $7,1^{\text {h-n }}$ & $53,4^{f-k}$ & $70.07 \mathrm{jk}$ & $10.13^{k}$ \\
\hline 34 & MSU 15019-44 & $23,7^{\text {h-I }}$ & 28,0 k-o & 6,6 j-n & 58,0 b-i & $73.90 \mathrm{~g}$ & $11.00 \mathrm{gh}$ \\
\hline 35 & MSU 15019-48 & 29,0 d-h & $35,9 a b$ & $10,4 \mathrm{bcd}$ & $52,2 \mathrm{~g}-\mathrm{k}$ & $66.33 \mathrm{~s}$ & $9.93 \mathrm{Im}$ \\
\hline 36 & MSU 15019-54 & $24,5 \mathrm{~g}-\mathrm{k}$ & 31,5 e-j & $7,7^{\mathrm{f}-\mathrm{m}}$ & $48,3 \mathrm{klm}$ & $68.70 \mathrm{mn}$ & $12.00^{f}$ \\
\hline 37 & MSU 15020-07 & $27,5^{d-j}$ & 32,8 b-h & 9,0 d-h & $62,7^{a-d}$ & $69.70 \mathrm{kl}$ & $12.00^{f}$ \\
\hline 38 & MSU 15020-15 & $22,7^{i-m}$ & 33,3 b-g & $7,6^{f-n}$ & 61,9 a-e & 68.10 op & $10.93 \mathrm{hi}$ \\
\hline 39 & Sari & $22,5^{i-m}$ & $26,5 \mathrm{~m}-\mathrm{q}$ & $5,8^{1-0}$ & $53,5^{f-k}$ & $72.80^{h}$ & 9.67 op \\
\hline \multirow[t]{2}{*}{40} & Cilembu & $17,7 \mathrm{Im}$ & 25,2 opq & $4,4^{\circ}$ & 58,7 b-h & $69.53^{\prime}$ & 13.27 e \\
\hline & LSD 5\% & 6,12 & 3,25 & 2,07 & 7,81 & 0,51 & 0,15 \\
\hline
\end{tabular}

\section{Kadar Gula Reduksi}

Terdapat lima klon yang memiliki kadar gula reduksi lebih tinggi dari varietas pembanding Cilembu (13,30 Brix) yaitu klon MSU 15008-22, MSU 15013-35, MSU 1501301, MSU 15016-69, dan MSU 15007-28. 33 klon menunjukkan kadar gula reduksi lebih tinggi dari varietas pembanding Sari. Tidak terdapat hubungan antara karakter morfologi tanaman dengan kadar bahan kering dan gula. Aksesi ubi jalar yang memiliki kadar gula tinggi tidak diikuti oleh kadar bahan kering tinggi demikian pula sebaliknya (Minantyorini dan 
Andarini, 2016). Lokasi budidaya ubi jalar Cilembu yang berbeda menunjukkan kadar gula total dan lama simpan maksimal yang berbeda, hal ini mengindikasikan faktor lahan berperan terhadap perbedaan kualitas kemanisan ubi jalar Cilembu (Solihin et al. 2017). Lebih lanjut juga dijelaskan faktor $\mathrm{pH}$ juga berperan pada tingkat kemanisan ubi jalar, ubi jalar Cilembu Rancing mempunyai kualitas kemanisan yang tinggi pada $\mathrm{pH}$ tanah agak masam dibandingkan netral atau agak basa. Beberapa unsur hara berperan sebagai aktivator enzim yang berperan dalam peningkatan kadar gula ubi jalar (Oktiarni, 2008 Dalam Solihin et al. 2017).

\section{KESIMPULAN}

Terdapat tiga klon yang berpeluang untuk dilepas sebagai calon varietas dengan potensi hasil dan kadar gula tinggi. Ketiga klon harapan tersebut mempunyai potensi hasil dan kadar gula lebih tinggi dibandingkan varietas pembanding Cilembu dan Sari, yakni klon MSU 15007-28, MSU 15008-22 dan MSU 15013-01. Untuk mengetahui tingkat konsistensi produksi dan kadar gula, maka klon-klon yang terseleksi akan diuji di beberapa lokasi untuk mengetahui tingkat adaptasinya.

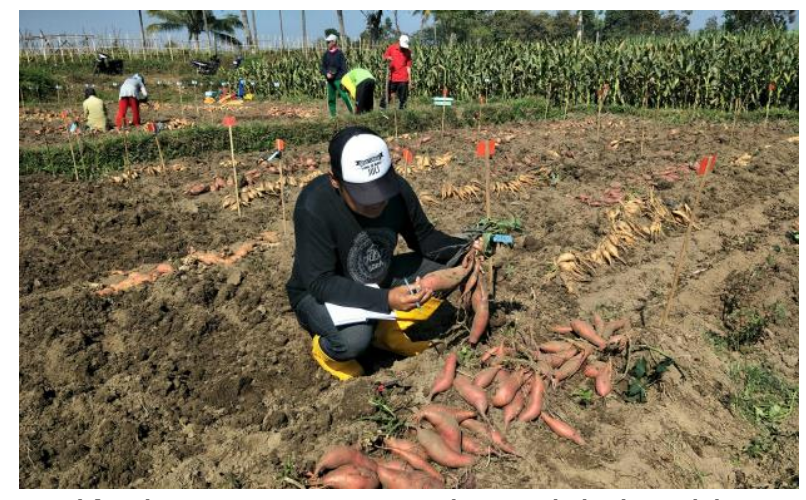

Kegiatan saat panen dan seleksi umbi

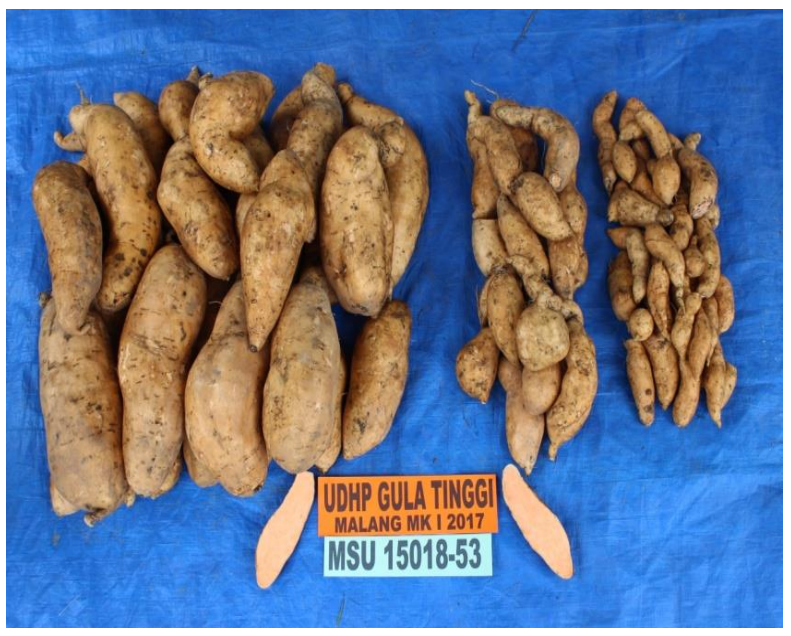

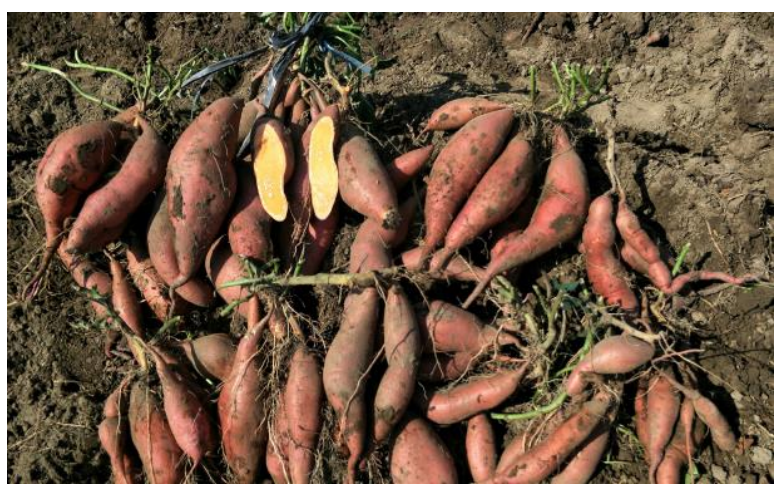

Contoh umbi hasil panen di sawah

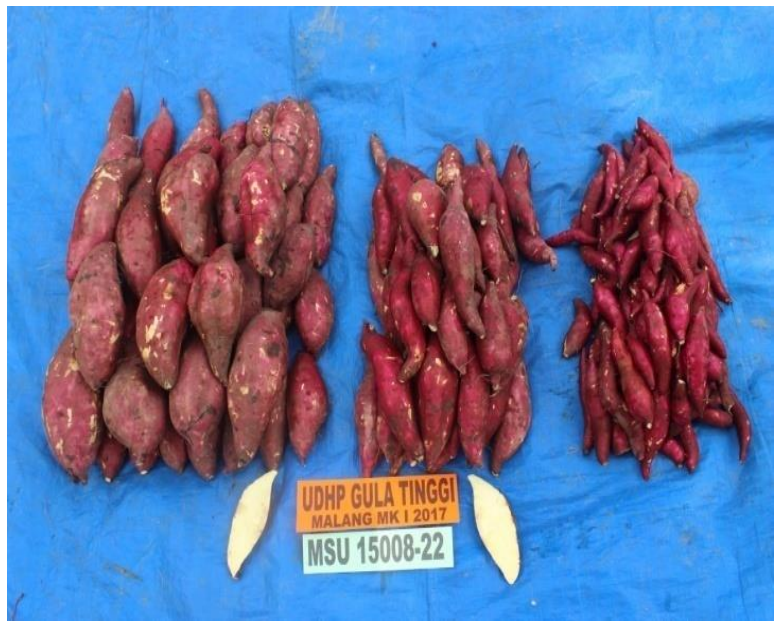

Beberapa contoh umbi yang terseleksi 


\section{UCAPAN TERIMA KASIH}

Ucapan terima kasih kami sampaikan kepada Kepala Badan Penelitian dan Pengembangan Pertanian Kementrian Pertanian atas dukungan dana sehingga penelitian ini dapat terselesaikan dengan baik. Ucapan terima kasih kepada Kepala Balai Penelitian Tanaman Aneka Kacang dan Umbi (Dr. Yuliantoro Baliadi, M.S)., Dr. M.Jusuf dan Ir. Erliana Ginting, M.Sc. yang telah memberikan dukungannya hingga terselesainya tulisan ini.

\section{DAFTAR PUSTAKA}

Adil WH. 2010. Karakterisasi Plasma Nutfah Ubi Jalar Berdaging Umbi Predominan. Buletin Plasma Nutfah 16 (2): 85-89.

Ambarsari I, Sarjana, dan Choliq A. 2009. Rekomendasi dalam Penetapan Standar Mutu Tepung Ubi Jalar. Balai Pengkajian Teknologi Pertanian. Jawa Tengah.

Fatonah w. 2002. Optimasi produksi selai dengan bahan baku ubi jalar cilembu. Skripsi. Fakultas Pertanian, Institutut Pertanian Bogor. $120 \mathrm{hlm}$.

Ginting, E., J.S. Utomo, dan M. Jusuf. 2012. Identifikasi sifat fisik, kimia dan sensoris klonklon harapan ubi jalar kaya beta karoten.hlm.612 - 623. In. Prosiding Seminar Nasional Hasil Penelitian Tanaman Aneka Kacang dan Umbi. Malang. 5 Juli 2012. (Eds). Rahmianna, A.A., E. Yusnawan, A. Taufiq, Sholihin, Suharsono, T. Sundari, Hermanto. Pusat Penelitian dan Pengembangan Tanaman Pangan, Bogor.

Indriani, F.C., M. Jusuf., S. Ashari., N.Basuki dan J. Restuono. 2016. Karakteristik plasma nutfah ubi jalar berdasarkan kandungan bahan kering dan karakter morfologi umbi. hlm. 530 - 539. In. Prosiding Seminar Nasional Hasil Penelitian Tanaman Aneka Kacang dan Umbi. Malang. 25 Mei 2016. (Eds) Rahmianna, A.A., D. Harnowo., Sholihin., N. Nugrahaeni., A. Taufiq, Suharsono, E. Yusnawan, E. Ginting, F. Rozi dan Hermanto. Pusat Penelitian dan Pengembangan Tanaman Pangan, Bogor.

Indriani, F.C., J. Restuono, dan S.Ashari. 2018. Kadar kalium dan korelasinya dengan karakteristik umbi pada ubi jalar. hlm. 150 - 159. In.Prosiding Seminar Nasional Peripi Komda Jatim 2017, Malang, 24 Agustus 2017. (Eds). Kuswanto, A.N. Sugiharto, M.D. Maghfoer dan N. Aini. Fakultas Pertanian. Universitas Brawijaya.

Jusuf M, Rahayuningsih SA, Wahyuni TS, Ginting E, Restuono J, dan Santoso G. 2006. Klon Harapan MSU 01015-07 dan MSU 01015-02, Calon Varietas Unggul Ubi Jalar Kaya Beta-Karoten. Inovasi Teknologi Kacang-Kacangan dan Umbi-Umbian. Mendukung Kemandirian Pangan \& Kecukupan Energi. hlm. 225-237.

Jha,G. 2012. Increasing productivity of sweetpotato [Ipomoea batatas (L.) Lam.] through clonal selection of ideal genotypes from open pollinated seedling population. International Journal of Farm Sciences. 2(2):17- 27.

Kure OA, Nwankwo L, and Wyasu G. 2012. Production and quality evaluation of garri- like product from sweet potatoes. Journal Natural Production and Plant Resources 2 (2):318-321.

Maulana, H., B. Waluyo, and Kurniawan. 2011. Status budidaya ubi jalar varietas Neerkom dan Eno di sentra produksi ubi jalar Cilembu Kabupaten Sumedang. Makalah. In Seminar Nasional Pemuliaan Berbasis Potensi dan Kearifan Lokal Menghadapi 
Tantangan Globalisasi. Kerjasama Peripi Komda Banyumas dan Lembaga Penelitian dan Pengabdian kepada Masyarakat Universitas.

Mekonnen, B., S. Tulu., J.Nego. 2015. Orange fleshed sweetpotato (Ipomoea batatas L.) varieties evaluated with respect to growth parameters at Jimma in Southwestrn Ethiopia. Journal of Agronomy 14(3): 164 - 169.

Minantyorini dan Y. N. Andarini. 2016. Keterkaitan karakteristik morfologi tanaman ubi jalar dengan kadar gula dan kadar bahan kering umbi. hlm. 530 - 539. In. Prosiding Seminar Nasional Hasil Penelitian Tanaman Aneka Kacang dan Umbi. Malang. 25 Mei 2016. (Eds) Rahmianna, A.A., D. Harnowo., Sholihin., N. Nugrahaeni., A. Taufiq, Suharsono, E. Yusnawan, E. Ginting, F. Rozi dan Hermanto. Pusat Penelitian dan Pengembangan Tanaman Pangan, Bogor.

Saitama, A., A. Nugroho., E. Widaryanto. 2017. Yield response of ten varieties of sweetpotato (Ipomoea batatas L.) cultivated on dryland in rainy season. Journal of Degraded and Mining Lands Management. 4(4): 919 - 926.

Saleh, N., St.A. Rahayuningsih dan Y.Widodo. 2008. Profil dan peluang pengembangan ubi jalar untuk mendukung ketahanan pangan dan agroindustri. Bul. Palawija No. 15: 21 30.

Solihin, M.A., S.R.P. Sitorus, A.Sutandi dan Widiatmaka. 2017. Karakteristik lahan dan kualitas kemanisan ubi jalar cilembu. Jurnal Pengelolaan Sumberdaya Alam dan Lingkungan 7(3):251 - 259.

Sudarmadji S, B Haryono, dan Suhardi. 1997. Prosedur Analisis Untuk Bahan Makanan dan Pertanian. Liberty. Yoyakarta.

Sudarmadji S, B Haryono, dan Suhardi. 1997. Prosedur Analisis Untuk Bahan Makanan dan Pertanian. Liberty. Yoyakarta

Wang, H. 1982. The breeding of sweet potatoes for human consumption. In R.L. Villareal and T.D. Griggs (eds.), In Sweet Potato, Proceedings of the First International Symposium AVRDC, Tainan, Taiwan: AVRDC, pp. 297-312. 